\title{
Iatrogenic Foreign Body in the Heart in Relation to Possible Malpractice and Its Consequences: A Case Report
}

\author{
Kalpte Olası Malpraktisle İlişkili İyatrojenik Yabancı Cisim Varlığı ve Sonuçları: Olgu Sunumu
}

\author{
Karol Karnecki, Michat Kaliszan, Zbigniew Jankowski
}

Department of Forensic Medicine, Medical University of Gdańsk, Gdańsk, Poland

\begin{abstract}
The paper presents the case of a 55-year-old man whose body was found at home at the foot of the stairs. The inspection of the body at the scene showed that the probable cause of the man's death was positional asphyxia after falling down the stairs. The forensic autopsy revealed a 10 -cm-long tip of a nephrostomy catheter. To determine the time and circumstances of the foreign body's entry into the heart and its possible impact on the man's death, the medical history was analyzed. It indicated that the piece of the catheter entered the circulatory system during surgery performed few years before man's death. The results of the postmortem examination, taking into consideration the obtained medical information, excluded the foreign body in the right ventricle of
\end{abstract} the heart as a contributory cause of the man's death.

Keywords: Foreign body, Heart, Catheter, Surgery, Positional asphyxia, Malpractice.

\section{Introduction}

The presence of a foreign body in the heart is an exceptionally rarely seen autopsy finding, particularly if it is large and a long time has passed between its entry into the body and death (1). The presence of a foreign body may result from a direct injury penetrating the chest near the heart or the abdominal cavity with diaphragm damage, or from the foreign body's transfer from a location distant from the heart, either via blood vessels or from the lumen of the digestive tract, e.g. from the esophagus or duodenum, or from the respiratory tract, e.g. the trachea (2-5). The presence of a foreign body in the heart most frequently has traumatic etiology, being the consequence of the use of firearms or injuries sustained due to the detonation of explosives (2,3). A foreign body can less frequently be the result of medical procedures, also in malpractice cases $(2,6)$. In case of the foreign bodies located in the heart it is most often a migration of the endovascular stent or piece of a catheter to the right ventricle $(2,7,8)$.

What happens with a foreign body in the cardiac cavities depends on its size and the manner of penetration of the heart:

Corresponding author: Michat Kaliszan MD, PhD

Department of Forensic Medicine, Medical University of

Gdańsk, ul. Dębowa 23, 80-204, Gdańsk, Poland

E-mail:michalkal@gumed.edu.pl

Tel: +48583491264, Fax: +48583410485

Geliș: 06.08.2015 Kabul: 05.11.2015

\section{Özet}

Bu yazı 55 yaşında evde merdiven basamakları başında ölü halde bulunan bir kişi ile ilgilidir. Olay yerinde cesedin incelenmesi kişinin muhtemel ölüm sebebini merdivenlerden düşme sonucu pozisyonel asfiksi olarak göstermektedir. Adli Tibbi otopside $10 \mathrm{~cm}$.lik nefrostomi kateter ucu tespit edilmiştir. Yabancı cismin kalbe giriş zamanı ve şeklini, ölüm üzerindeki etkisini saptayabilmek için kişinin tıbbi özgeçmişi de araştırıldı. Katater parçasının adamın ölümünden birkaç yıl once once uygulanan cerrahi işlem sırasında dolaşım sistemine girdiği anlaşıldı. Postmortem inceleme sonuçları ve alınan tıbbi bilgiler değerlendirildiğinde, kalpte sağ ventrikülde bulunan yabancı cismin, kişinin ölümüne katkıda bulunacak neden oluşu dışlanmaktadır.

Anahtar kelimeler: Yabancı cisim, Kalp, Kateter, Cerrahi, Pozisyonel asfiksi, Malparktis.

from the right ventricle the body may return to the venous system (via the superior or inferior caval vein), flow with the blood current to the pulmonary artery or remain in the ventricle, jammed in the trabeculae carneae $(2,3)$. In the rare case of a defect in the atrial septum, this may lead to a so-called paradoxical embolism and the foreign body finding its way to the systemic circulation $(2,4)$. The complications (symptoms) of a foreign body in the heart can be divided into two groups: early ones including myocardial infarction, bleeding to the pericardial sac with secondary cardiac tamponade, recurrent fluid in the pericardial sac and pericarditis, and late ones, i.e. chest pain, cardiac aneurism, neurological disorders and thromboembolic complications $(2,9)$. The most frequent symptoms associated with a foreign body in the heart are fever, pericarditis, fluid in the pericardial sac, arrhythmia and neurological symptoms, mostly anxiety $(2,3)$.

\section{Case Report}

\section{Death scene}

The body of a 55-year-old man was found in June 2013 at the base of a steep staircase in a residential building. The man was lying on the floor with his head leaning on a cupboard. Ambulance arrived at the scene and his death was pronounced. It was established on the spot that in his lifetime the man had 
suffered from an unspecified heart condition, diabetes and alcoholic epilepsy, he had had a problem with alcohol and had purportedly drunk 3 beers on the day preceding death.

During the examination of the man's body at the site of its discovery it was found that the head and neck integuments were livid, with extravasations in the upper part of the chest. Apart from chafes on the face, no other injuries were found on the integuments of the body. The entire picture (the witness's testimony and the body position) suggested death due to the closure (obstruction) of the respiratory tract as a result of socalled "positional asphyxia".

\section{Autopsyfindings}

The examination of the man's body revealed: slight chafes and scanty bruises on the facial integuments, a single bruise on the back on the left-hand side and slight chafes on the fingers of the right hand. The postmortem additionally showed organs congestion, edema and overinflation of the lungs, hemorrhages in the gastric mucosa and a surgical scar in the left hypochondriac region. Moreover, the examination revealed an old focus of malacia in the right temporal lobe and left occipital lobe of the brain, a nodular goiter, slight generalized atherosclerosis, hepatic steatosis and left-sided hydronephrosis. Finally, after the opening of the right ventricle of the heart, a foreign body was found in the form of a $10-\mathrm{cm}$ long and $0.5 \mathrm{~cm}$ in diameter piece of plastic tube, resembling the tip of a catheter (Fig. 1). The microscopic examination showed: in the brain - extensive glial scar; in the lungs excessive foci of aeration with signs of acute distension; in the heart - a small thickening of the wall of coronary arteries, with narrowing of their lumen, slight cardiocytes hypertrophy; in the liver - multifocal hepatocyte steatosis; in the kidneys and spleen - significant congestion; in the pancreas - diffuse, focal blood extravasations, and in the thyroid gland - a nodular goiter. The toxicological examination showed no alcohol in the blood and urine.

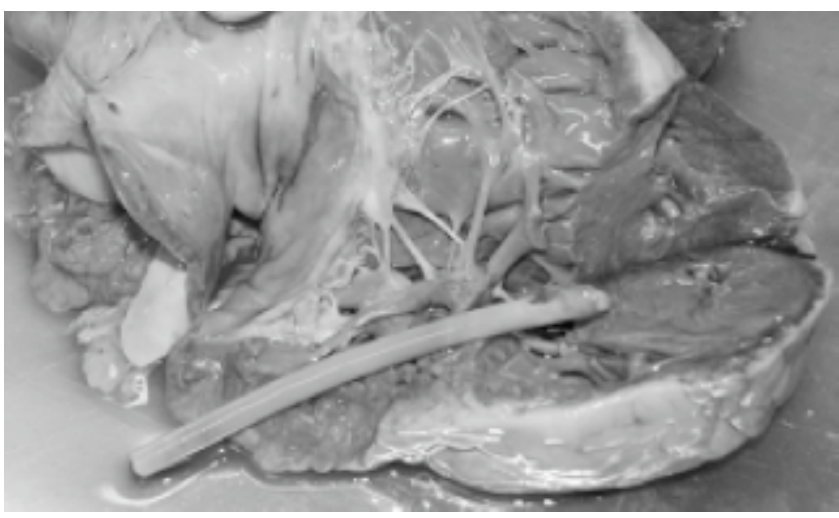

Figure 1. A 10-cm long catheter fragment revealed in the right ventricle of the heart

\section{Medical records}

According to the medical records, in 2009 the man was hospitalized due to purulent post-traumatic hematomas in the retroperitoneal space on the left, also near the left renal pole. Initially he was treated non-invasively on the internal ward, and then, since his general condition failed to improve, on the urology ward, where he had preliminary drainage of the retroperitoneal space. Due to continuing fever an abdominal CT scan was performed which revealed a retroperitoneal abscess. During an attempt at retroperitoneal space drainage, profuse bleeding developed, therefore an emergency lumbotomy with revision of the left retroperitoneal space and drainage of the abscess was performed. The description of the procedure indicates that during the opening of the integuments a previously inserted Nelaton $16 \mathrm{~F}$ catheter was accidentally cut and a piece of it was not found in the operative field. It was assumed that it had probably been thrown away with drapes to the bin. The anesthesia and premedication chart shows that in the course of the surgery a few atrial fibrillation episodes lasting several seconds were observed and they subsided spontaneously. After 13 days of hospitalization the patient was discharged in a good general condition.

In 2010, the man was hospitalized twice on a surgical ward of a district hospital due to craniocerebral injuries secondary to epileptic seizures, and then he was secured successfully with antiepileptic medications. From 2010 to the time of his death the man did not report any significant health complaints.

\section{Discussion}

The results of the postmortem examination, taking into consideration circumstances of body discovery and medical records, indicated that the cause of the man's sudden death was most probably so-called "positional asphyxia" after falling down the stairs. The scene and medical records suggest that the cause of falling the stairs could be accidental stumble, or else collapse due to either vertigo, cardiac arrhythmia or epilepsy seizure.

Neither the postmortem nor the histopathologic examination showed any consequences of the long-lasting presence of a catheter in the right ventricle of the man's heart that might have caused his death. The autopsy permitted to exclude both early complications of a foreign body in the heart, namely myocardial infarction, bleeding to the pericardial sac with secondary cardiac tamponade and fluid (transudate) in the pericardial sac with secondary pericarditis, and late consequences such as pulmonary embolism and neurological disorders due to thromboembolic lesions and cardiac aneurysm. 
Based on the above data, it was concluded that there were no grounds to assume that the man's death was even partially caused by the foreign body in the right ventricle of the heart, which might have been a complication of the surgery performed 3.5years before.

The most frequent reason for a foreign body in the heart are gunshot wounds inflicted by both firearms and fragments of explosive charges (2-5). Much less frequently, it is the consequence of medical procedures, including blood vessel cannulization $(7,8)$. In the studied case, the foreign body - a Nelaton catheter tip - most probably entered during surgery as a result of an accidental cut of the catheter and the renal or caval vein, and the cut catheter tip getting into the vein and then being transported by the inferior caval vein to the right atrium and eventually to the right ventricle of the heart. This would explain profuse bleeding reported during surgery, however the surgeon did not report suturing of the lanced vein. In the available literature we have not found a description of the iatrogenic complication of retroperitoneal abscess drainage such as the presented case. There are, however, reports of complications of cardiac catheterization, where retention of a catheter in the heart occurs in $0.07 \%$ of the cases (10).

The medical treatment in case of a foreign body in the heart is individualized in each case and depends on the type and size of the body, the route of its entry and the localization in the heart as well as on possible concomitant symptoms $(2,3,10)$. It is said that foreign bodies embedded in the myocardium or pericardium of non-symptomatic patients should be monitored $(1,3-5,9)$. Non-invasive treatment is also recommended in cases of foreign bodies located in the right part of the heart and those found after many years of their entry into the circulatory system $(2,5,9)$.

In summary, the case showed that a foreign body in the heart is a rare finding that may cause difficulties in establishing the cause and mechanism of death. Nevertheless, a carefully conducted postmortem with an analysis of medical history may enable the establishment of the cause and mechanism of death, taking into consideration the possible impact of a foreign body in the heart on death.

\section{Conclusion}

The presented case is the first reported iatrogenic complication of retroperitoneal abscess drainage through the sucking of a fragment of an accidentally cut catheter into the venous system with its passage to the right ventricle of the heart. Further, this case demonstrates that a foreign body in the heart, even as big as a 10-cm fragment of a Nelaton catheter, does not necessarily cause death or other health problems, despite its retention in the right ventricle of the heart for few years. Owing to its flexibility, the catheter in the lumen of the right ventricle of the heart would bend with the contracting myocardium, without causing any complaints. Therefore, even if it is assumed that in the presented case we are dealing with malpractice, it did not cause the negative health repercussions and did not contribute to patient death.

\section{References}

1. LeMaire SA, Wall MJ, Mattox KL. Needle embolus causing cardiac puncture and chronic constrictive pericarditis. Ann Thorac Surg. 1998;65(6):1786-1787.

2. Actis Dato GM, Arslanian A, Di Marzio P, Filosso PL, Ruffini E. Posttraumatic and iatrogenic foreign bodies in the heart: report of fourteen cases and review of the literature. J Thorac Cardiovasc Surg. 2003;126(2):408-414.

3. Symbas PN, Picone AL, Hatcher CR, Vlasis-Hale SE. Cardiac missiles. A review of the literature and personal experience. Ann Surg. 1990;211(5):639-647.

4. Moncada R, Matuga T, Unger E, Freeark R, Pizarro A. Migratory traumatic cardiovascular foreign bodies. Circulation. 1978;57(1):186-189.

5. Schechter DC, Gilbert L. Injuries of the heart and great vessels due to pins and needles. Thorax. 1969;24(2):246-253.

6. Mannea C, Sarafoleanu C. Iatrogenic foreign bodies in the maxillary synus: between malpraxis and medico-legal consequences. Rom J Leg Med. 2015;23: 14-18.

7. Bobylev D, Meschenmoser L, Boethig D, Horke A. Migration of an endovascular stent into the right ventricle following deployment in the inferior vena cava after liver transplantation. Eur J Cardiothorac Surg. 2014. doi: 10.1093/ejcts/ezu436

8. Vertolli U, Davis PA, Calò LA. Fractured catheter guide wire in the right ventricle of a dialysis patient. Nephrology. 2014;19(1):61-62.

9. Holdefer WF, Lyons C, Edwards WS. Indications for removal of intracardiac foreign bodies: review and report of four cases. Ann Surg. 1966;163(2):249-256.

10. Choi $\mathrm{CH}$, Elahi MM, Konda S. Iatrogenic retained foreign body in the right atrium. Lessons to Learn. International Journal of Surgery Case Reports. 2013;4(11):985-987. 